Claudia Mitchell

\title{
CHALleNGING TURBULENT TIMES: TOWARDS A FRAMEWORK FOR GIRL-LED TRANSNATIONAL DIALOGUES TO COMBAT SEXUAL VIOLENCE
}

Turbulent times in relation to sexual violence in the lives of girls and young women call for solidarity and global action. One of the effects of globalization is the increased recognition of a borderless world that, in some ways, erases the boundaries between 'over there' and 'over here', challenging some of the distinctions behind a Global North and a Global South. In this article, I offer an analysis of the issues behind sexual violence, which frame the possibilities for research teams working with girls and young women across the Global North and the Global South. At the same time, I highlight the possibilities for learning more about North-North and South-South interactions. What would such an approach entail and what kinds of strategies are useful for sustaining such a strategy in combating sexual violence? In particular, how can such a framework support dialogue? In order to address these questions the article suggests a practical framework which draws on the findings from a Canada-South Africa project, Networks for Change and in particular focuses on the importance of advocating for a public voice for girls and young women that is framed within an activist agenda. The article refers to this approach as a 'circles within circles' approach, arguing for both bringing together girls and young women who have been involved in participatory visual work from a number of country contexts, and ensuring that the circle puts girls and young women at the centre.

Keywords: dialogue; girls and young women; participatory methodologies; sexual violence

DOI: $10.17323 / 727-0634-2018-16-3-517-528$

Claudia Mitchell - PhD, James McGill Professor, McGill University, Montreal, Canada. Email: Claudia.mitchell@mcgill.ca 


\section{Context}

One of the effects of globalization is the increased recognition of a sometimes borderless world which erases an 'over there' and 'over here', and which diminishes some of the distinctions between the idea of Global North and Global South. Nowhere is this more apparent than in concerns about the well-being of girls and young women in relation to sexual violence. We see this in the now widespread \#MeToo Movement. In the Canadian context, we have become increasingly aware of the shameful situation of the many missing and murdered Indigenous women and girls. Statistics highlight that Indigenous women are 2.5 times more likely to be victims of violence, and six times more likely to be killed (Miladinovic, Mulligan 2015: 14) than non-Indigenous women.

This concern for the safety and security of girls and young women was evident at a roundtable on gender and circumpolarity convened by the Gender Forum at the University of Mid-Sweden in October 2015. In bringing together feminist scholars from Norway, Sweden, Russia, Finland, and Canada, it was clear that, while the idea of 'North' occupies very different meanings in these various countries (particularly in relation to Indigenous and non-Indigenous peoples), there are many critical convergences when it comes to the lives of girls and young women, with high rates of sexual violence and challenges to their well-being clearly at the top of the list. Speaking of the popular perception that Nordic girls are the 'ones who won the lottery', Finnish scholar Elina Oinas (2011) reminds us of the increasing recognition of the limitations of talking about these critical convergences about 'the North' in the absence of dialogue with and about the social and material contexts of 'the South.' We know that worldwide these numbers are particularly shocking in relation to girls and young women: over 120 million girls (one in ten) report some form of sexual violence (UN Women 2017).

The Sustainable Development Goals (SDGs) that call for good health, well-being, and gender equality (United Nations 2018) highlight the significance of a global agenda. With the transition from the Millennium Development Goals to the SDGs, girls' completion of secondary education is now positioned as a key strategy to achieving the entire 2030 Agenda. The 2016 UNFPA State of the World Population report, 10: How our Future Depends on a Girl at this Decisive Age (UNFPA 2016), identifies the age of ten as a critical turning point in girls' lives. The girls who were 10 -years-old at the start of the SDGs in 2015 will be 25 years old by 2030. During this transition from girlhood to adulthood, a number of decisions will affect girls' experiences and social positions related to puberty, schooling, sexual health, marriage, childbirth, and entry into the paid workforce. The success of the SDGs depends on investing in policies, institutions and strategies that support girls, as well as their families and communities through these decisions. But what might sustainability look like in the context of addressing sexual violence in this global 
context and what strategies might be particularly promising in relation to what have come to be called 'turbulent times' for girls and young women?

In this article, I consider one area of promise and hope, that being dialogue that starts with girls and young women themselves. In so doing I draw on instances where this dialogue is currently happening in a six-year partnership project Networks for Change and Well-being: Girl-led 'From the Ground Up' Policy to Address Sexual Violence in Canada and South Africa (Moletsane, Mitchell 2018). I point to the development of a framework that I refer to as 'circles within circles' (See, Ely 1991) and which seeks to keep this type of dialogue going between and among girls and young women across a number of country contexts.

\section{Networks for Change: Girl-led Learnings across Two Countries}

I start with a short description of Networks for change and wellbeing: Girl-led 'from the ground up' policy making in addressing sexual violence in Canada and South Africa (hereafter referred to as Networks for Change). This is a six-year, international and interdisciplinary partnership led by McGill University in Canada and the University of KwaZulu-Natal (UKZN) in South Africa, with partnership made up of universities in Canada and South Africa, girl-focused organizations in each country, and several key national and international organizations and stakeholders responsible for policy and programing related to girls' lives. As a participatory research project, Networks for Change seeks to understand and address sexual violence against girls and young women in rural South African and in various Indigenous contexts in Canada. While the two country contexts are different in many ways, there some dramatic convergences. South Africa is known to have one of the highest rates of sexual assault in the world, with adolescent girls between the ages of twelve and seventeen being particularly at risk, and there is a persistent and, in a sense, unrelenting possibility of sexual violence that runs counter to girls' safety and security in schools and communities (Moletsane et al. 2015).

Similarly, investigations into the lives of girls in Canada reveal that girls, especially those who are marginalized as a result of race and disability, experience many subtle and overt forms of violence, particularly in the context of relational, community and settler colonial violence (Berman, Jiwani 2002; De Finney 2015). Because much of this violence - occurring in schools, the community, in intimate settings, and on the street - can be so pervasive, victimization can easily go unnoticed. Indeed, girls themselves often accept violence or fail to identify it as such when it occurs (Berman, Jiwani 2002; Wolfe, Chiodo 2008). In their review, researchers (Collin-Vézina, Trocmé 2009) found an estimated $25-50 \%$ child sexual abuse prevalence rate in Aboriginal adults surveyed in several communities across Canada over the past 20 years. Aboriginal women continue to face high rates of sexual assault and abuse: they are 
eight times more likely than non-Aboriginal women to be killed by an intimate partner (Sinha 2013). Across Canada, commercial sexual exploitation of Aboriginal youth and children forms more than $90 \%$ of the visible sex trade (Kingsley, Mark 2000). Aboriginal women confront a constellation of factors that contribute to sexual violence: colonization and its components of patriarchy, racism, and sexism; residential schools; historical trauma; Bill C-31 that determines Indian status and its accompanying band compensation, infrastructure, support, as well as access to their community of origins. Many girls do not report sexual attacks at all because of the complex jurisdictional issues on and near reservations. Similar to the situation of many girls in South Africa, displacement is a concern. Aboriginal girls are pushed into extremely dangerous situations because of policies (e.g. Bill C-31) that force them to move away from their communities; they are isolated in situations of heightened danger stemming from sexualized racism, sexism, poverty, and through criminalization where historical dislocation and devaluation collide.

What is of concern to the partners in Networks for Change is that the statistics on sexual violence for girls under the age of eighteen in both country contexts are shocking and call for an intensifying of effort in relation to addressing the lived realities of girls who are marginalized and who suffer from persistent insecurity, injustice, and abuse of power at the local level in otherwise democratic states. The partnership aims to influence the ways in which the voices of girls can inform local, national, global and virtual communities in relation to curbing sexual violence. Thus, to understand the dynamics in the two contexts, the Networks for Change project seeks to study and advance the use of innovative approaches to programming, knowledge-production, policy making and communication in addressing sexual violence amongst girls and young women. While sexual violence is a global issue, the partnership specifically interrogates the ways in which the participation of girls in democratic societies could be and indeed must be transformative.

Working with girl-led initiatives addressing gender violence in two democratic country contexts, Canada and South Africa, the program focuses on 'from the ground up' policy-making organized around 'girl-led' methodologies such as participatory video and cellphilm production (cellphone combined with video), photo-voice and digital storytelling (see also, De Lange et al. 2015; Mitchell, De Lange 2015). In Canada, the project is organized around fieldsites in four provinces: Nova Scotia, Quebec, Saskatchewan and British Columbia. In South Africa, the research project is organized around rural school communities in the provinces of KwaZulu-Natal, the Free State and Eastern Cape. In this project, there are three different circles of players and actors, with girls and young women at the centre of the dialogue: (1) Researchers from girlled projects in 2 countries (Canada and South Africa); (2) Key Canadian and South Africa partner NGOs /regional organizations; (3) A global organization focusing on girls and young women and sexual violence (UNGEI). 


\section{Lessons learned from Networks for Change}

In the first three years of Networks for Change there have been a number of key lessons learned, based on what the girls and young women are saying and producing through their videos, cellphilms, exhibitions, policy posters and action briefs (Mitchell et al. 2017a; Moletsane, Mitchell 2018). I highlight five of these below.

Firstly, it is Urgency: Perhaps at the most basic level, what we are seeing is that the time frames for girls and young women are very different from what is typically seen in adult-driven projects. There is an urgency that makes the participants typically action-oriented; they want to see things happen. Many of the datagathering events take place as part of residential weekend events or weeklong workshops during the school holidays. This type of scheduling allows for the kind of intensity that we often see. The participants want to finish their cellphilm or poster quickly and are anxious to move the productions to the next level. While there is rich evidence from the literature on youth activism of this type of intensity and 'youth-led' commitment, we highlight it here because so much of the work of this project is outside of the DIY (do it yourself) movement in that the events are typically adult organized (within the project) but can still be girl-led.

Secondly, Risk-taking: Another key feature of the work links to the recognition that young girls and young women are more likely to be risk-takers and innovative in relation to issues that affect their lives in ways that adults might not be. We have seen this in the vast range of technologies they have been willing to test out and the artistic platforms that they have seized when it has been possible to speak out. The idea that they have been keen to try photovoice and cellphilming and digital storytelling is a good example of their risk-taking and especially in addressing issues that could be considered very controversial in the community.

Thirdly, Sexual violence is not a single issue for girls and young women: Something that has also been critical is the fact that the participants do not see sexual violence as a single issue. Rather it is entangled in issues of poverty, race, pregnancy, HIV and AIDS. Participants want to talk about their own sense of themselves in their communities, relationships with family, and poverty. In both country contexts, the idea of land dispossession becomes a feature of colonial and patriarchal structures in the everyday lives of Indigenous girls and young women.

Fourthly, Future orientation: One of the most common narratives across a range of field sites is concerns about their future. The work is not just now but must also be 'what next?' As we consider our positionalities as researchers in this project, this future oriented work highlights the responsibilities of researchers and practitioners.

Finally, there is Dialogue: Talking with and talking to are key features of this work. While this is of course related to the significance of ensuring that cellphilms and photo exhibitions are viewed by community members, dialogue across sites and across country contexts is also key. In the second year of 
the project, for example, Canadian young women from the National Indigenous Young Women's Council visited South Africa and met up with young women from the Girls Leading Change group at Nelson Mandela University. During the second and third years of Network for Change, Indigenous young women from Canada were interns in South Africa and participated in the fieldwork. In the third year of the project, Girls Leading Change visited a university site in the US. What we are seeing is how valuable this aspect of the project in that there is so more awareness of the national and international politics attached to combating sexual violence. In the Networks for Change project, for example, indigenous young women in Canada and South Africa are working together to create an international advisory panel on indigenous girls leading change in the area of sexual violence. While some of the participants have met face-to-face as I note here, what they are also seizing on is the value of social media to keep the alliance active.

These activities have paved the way, as I explore below, to imagining and putting into place new frameworks for supporting interventions that are led by girls and young women.

\section{Expanding the Circles within Circles Network: A Practical Framework}

While Network for Change has been contributing to the idea of 'girl-led' engagement in relation to two country contexts, one in the Global North and one in the Global South, it is an area that clearly requires greater focus in relation to 'from the ground up policy making'. What can be learned by looking across a variety of country contexts and how can this work inform policy across a variety of policy contexts that pertain to sexual violence (education, health, social development, immigration, and justice)? We also need to know more about how girls and young women who are at a particular stage of their lives can still be part of the policy cycle and what difference the various contexts (for example, education, health) make. Finally, we need to know more about the sustainability of these initiatives, which, so often, are simply project-by-project. What difference would it make to have national, regional, and global partners in this work?

The national and global contexts in which I am working as a scholar with a base in both Canada and South Africa have afforded opportunities for projects with girls and young women that seek to ensure that this work is girl-led. This has meant refining participatory visual methods as approaches that capture local knowledge, and that help to make that knowledge available for others through exhibitions, screenings, and digital curation. As can be seen in Figure 1 these various projects have North-North, North-South, South-South, and pan-national configurations. I offer this configuration as an example of the types of transnational that would be possible building on a series of already existing projects and partnerships. 

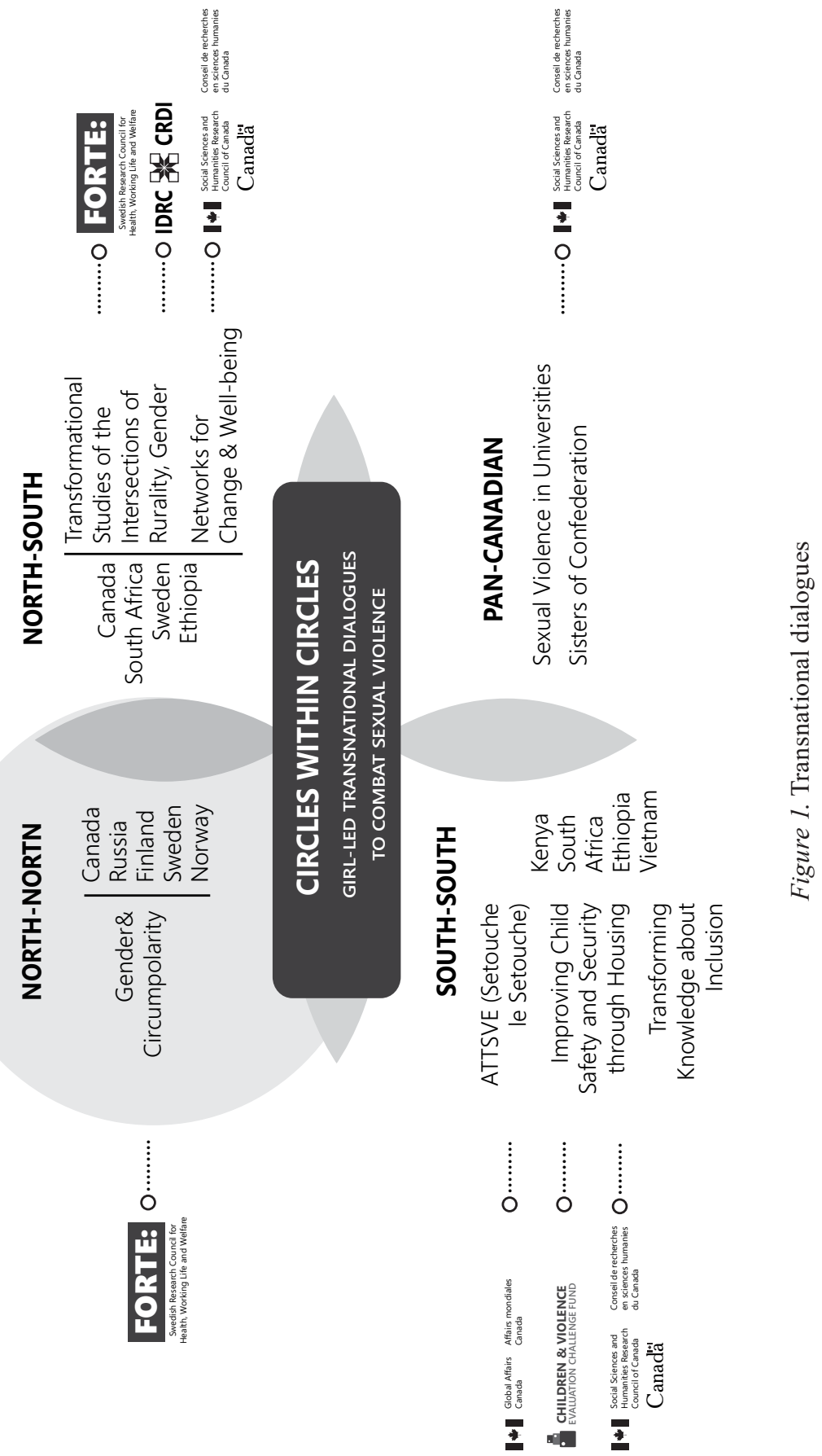
But what is required to facilitate the various forms of dialogue needed to support transnational perspectives? Below I list several types of activities and initiatives that can be carried out within a Circles within Circles framework.

Residential Think Tanks: At the heart of this type of project is the idea of bringing together key players from each of the three circles in face-to-face dialogue with girls and young women. It is meant to set the stage for expanding the dialogue and interplay with girls and young women representing alreadyexisting girls' advisory panels involved in participatory visual work on sexual violence. The focus of such an event is to build momentum and solidarity between and amongst the girls and young women and participants representing the three circles, particularly in relation to advancing girl-led media making and dialogue. Such an event can also showcase what is already happening and serve as a foundation for working together both for media production in relation to policy change and for embarking upon a way to capture community and policy dialogue. ${ }^{1}$

Fieldwork through Girl-Focused Media-Making Workshops: A key component would be follow-up fieldwork, based on a series of girl-focused media making workshops taking place in six to nine countries, building on the wellestablished digital practices of Networks for Change and especially the use of the cell phones to produce short cellphilms. The fieldwork and media-making training could be facilitated over a period of several months through digital workshops at which groups of girls and young women at each site will use cell phones, tablets or other devices to create cellphilms to 'picture well-being'. These workshops would not simply be about media making but also about dialogue and the significance of images that girls and young women want to produce to inform transnational dialogue about combating sexual violence. A special feature of the project is to make sure that there is an opportunity for a follow-up workshop in each setting where cellphilms can be screened, discussed, and, in some cases, even 'revised' through what has been described elsewhere as a 'speaking back' method (Mitchell et al. 2017b).

Creating an Online Web Portal: Ensuring good digital and social media platforms is also critical. An online portal can serve as a communication tool for the Network, but could also serve as a blog and gallery space for Digital Exhibitions. Such a gallery space could include cellphilms and other digital media from the six to nine countries represented, and addressing critical issues related to sexual violence as identified by girls and young women.

Producing Policy Briefs and Support-to-Policy Webinars: An important feature of this work is 'getting the word out' through for example policy briefs

\footnotetext{
${ }^{1}$ The first residential think tank has now taken place. This transnational event occurred at Montebello, Quebec, July 8-11, 2018 and brought together girls and young women along with researchers and NGOs from Canada, South Africa, Kenya, Russia and Sweden, and also featured an art exhibition 'Speaking Back' with images related to combating gender violence from six countries.
} 
and briefing papers organized around key themes such as the following: (a) Girls and media making in under-resourced settings; (b) Evidence for 'from the ground up policy making'; (c) Girls and young women as knowledge producers in the area of sexual violence. This work could support knowledge translation through a series of method-focused webinars designed for different audiences including other researchers, policy makers and girl-led activist groups.

\section{Discussion}

The idea of dialogue and its significance within Networks for Change points to the importance of supporting and sustaining dialogue in innovative ways. Here we might think of youth and political activism and the notion of the public voice of girls and young women. To date this has been studied largely in the arena of online activism and youth studies (as opposed to a focus on girls and young women). It has been noted (Rheingold 2008; Jenkins et al 2009), for example, that when adolescents and young adults engage with online participatory cultures and digital communication (blogging, social media networking, instant-messaging and online sharing of user-generated content), they are learning to develop a public voice (see also, Caron et al. 2016). Civic engagement (political activism, deliberation, problem solving) requires the effective use of a public voice (Levine 2008; Rheingold 2008).

Peter Levine observes that 'a public voice is always one that can persuade other people - beyond the closest friends and family - to take action on shared issues' (2008: 120). He differentiates between a private voice as one that is not intended to interest a community or to address broader concerns. An example of a private voice, Levine explains, is an e-mail or a social networking site that is meant for people close to the one writing the message. By contrast, a political blog is an example of a public voice, where the author expresses opinions/perspectives on current issues to draw or influence a larger audience. Levine makes the point that a public voice is not limited to addressing political matters, but also comprises cultural production, where engaged people come together in communities or associations. Topics thus extend beyond politics to include discussing bad software, how to fix technical problems, and poor customer service, for example, but of course they can also focus on the local or national contexts for sexual violence. As has been noted elsewhere (Mitchell et al. 2017a) much of this work on public voice and civic engagement remains gender neutral, or privileging male youth as participants. In studies that do focus on the participation of girls and young women in addressing gender violence, the notion of how this work can inform policy and programming is typically neglected or offered as 'next steps'.

The example of Networks for Change responds to the idea of young women and activism in relation to sexual violence which has been an understudied area of youth activism, and locates the project within an emerging 
body of work on young women as activists (see, MacKay 2011; Taft 2010; Trigg 2010). As Jessica Taft observes in Rebel Girls:

Girls' activism is an extremely underexplored scholarly topic, largely invisible in the academic literatures on girlhoods and on social movements. Research in the growing field of girls' studies has focused primarily on girls' self-esteem and psychology, sexuality and sexual behavior, friendships, schools and peer relationships, media consumption, production and cultural practice, and issues of growing up and constructing identities in various contexts (Taft 2010:8).

As she goes on to comment: 'These works often describe girls' acts of resistance to dominant gender norms, or address girls' consumption of commodified versions of feminism, but very few have made girls' politics or political identities the central focus of study' (Ibid). She describes activist strategies of girls and young women in North America and Latin America where girls spoke about the value of political education as an activist tool, highlighting the place of teach-ins, cultural events, screening of films and so on. She notes one significant difference between girls in North America and girls in Latin America where girls have a mastery of political language. As she writes: 'Compared to their North American peers, Latin American girls have more places where they can practice expressing their critical knowledge, expand on their skills of political analysis, and learn more extensive political vocabularies' (Ibid: 109). As a consequence, Latin American girls expressed more confidence in formal political spaces than North American girls, who struggled to find the right political language to voice their needs and concerns.

Taft's comparisons offer a compelling reason to seek transnational perspectives. A Circles within Circles framework as described above offers the opportunity to deepen an understanding of what girl-led transnational perspectives on combating sexual violence could look like and how this work is specifically linked to dialogue and activism. At the same time, there may be a number of critical questions to ask: To what extent, for example can there be an activist agenda to combat sexual violence for girls and young women who are at the very same time themselves discovering and performing their sexual identities? How do we ensure that 'girl-led' also means that adults also take responsibility? Influencing policy may vary greatly from one country to the other, or even from one context to another in the same country: how might the framework above help to accommodate these differences?

\section{Conclusion}

The need for new strategies for enhancing and sustaining the engagement of girls and young women to combat sexual violence is critical. As we are reminded daily through social media and newscasts, the situation for girls and young women remains precarious and it is tempting to think of the idea of combating the everyday occurrences of sexual violence as outside the range of 
possibilities for ordinary citizens and especially for girls and young women. As the title of the article suggests, these are turbulent times. However, as projects such as Networks for Change are suggesting, the notion of change starts with dialogue: girls in dialogue with researchers, teachers, community leaders, and also in dialogue and with each other. The possibilities for learning across contexts has been highlighted here, building on one case study of a Canada-South Africa partnership, but with the suggestion of how this type of work is being expanded from a North-South configuration to one that could include North-North and South-South linkages.

\section{Acknowledgements}

I am grateful to the Pierre Elliot Trudeau Foundation for its support for the idea of the Circles within Circles. This work was also supported through a Social Sciences and Humanities Research Council of Canada (SSHRC) grant (award number 895-20133007) and an International Development Research Centre (IDRC) grant (award number 107777-001).

\section{References}

Berman H., Jiwani Y. (2002) In the Best Interests of the Girl Child Phase II Report. The Alliance of Five Research Centres on Violence. Available at: http://www.unb.edu/fredericton/ arts/centres/mmfc/_resources/pdfs/bestinterest_e.pdf (accessed 8 July 2018).

Caron C., Raby R., Mitchell C., Thewissen-Leblanc S., Prioletta R. (2016) From Concept to Data: Sleuthing Social Change-oriented Youth Voice on YouTube. Journal of Youth Studies, 20 (1): 47-62.

Collin-Vézina D., Dion J., Trocmé N. (2009) Sexual Abuse in Canadian Aboriginal Communities: A Broad Review of Conflicting Evidence. Pimatisiwin: A Journal of Aboriginal and Indigenous Community Health, 7 (1): 27-47.

De Finney S. (2015) Playing Indian and Other Settler Stories: Disrupting Western Narratives of Indigenous Girlhood. Continuum: Journal of Media \& Cultural Studies, 29 (2): 169-181.

De Lange N., Mitchell C., Moletsane R. (2015) Girl-led Strategies to Address Campus Safety: Creating Action Briefs for Dialogue with Policy Makers. Agenda, 29 (3): 118-127.

Ely M. (1991) Doing Qualitative Research: Circles within Circles. London: Routledge.

Jenkins H., Purushotma R., Weigel M., Clinton K., Robison A. J. (2009) Confronting the Challenges of Participatory Culture: Media Education for the 21st Century. Available at: http://files.eric.ed.gov/fulltext/ED536086.pdf (accessed 8 July 2018).

Kingsley C., Mark M. (2000) Sacred Lives: Canadian Aboriginal Children and Youth Speak Out about Sexual Exploitation. Vancouver, BC: Save the Children Canada.

Levine P. (2008) A Public Voice for Youth: The Audience Problem in Digital Media and Civic Education. Civic Life Online: Learning how Digital Media can Engage Youth:119-138.

Mackay F. (2011) A Movement of their Own: Voices of Young Feminist Activists in the London Feminist Network. Interface: A Journal for and about Social Movements, 3 (2): 152-179. 
Miladinovic Z., Mulligan L. (2015) Homicide in Canada, 2014. Available at: http://www. statcan.gc.ca/pub/85-002-x/2015001/article/14244-eng.pdf (accessed 8 July 2018).

Mitchell C., De Lange N. (2015) Interventions that Address Sexual Violence against Girls and Young Women: Mapping the Issues. Agenda, 29 (3): 3-12.

Mitchell C., Moletsane R. (eds.) (2018) Disrupting Shameful Legacies: Young People Engaging in the Arts and Visual Practice to Address Sexual Violence. The Hague: Brill.

Mitchell C., De Lange N., Moletsane R. (2017a) Addressing Sexual Violence in South Africa: 'Gender Activism in the Making'. E. Oinas, H. Onodera, L. Suurpää (eds.) What Politics? Youth and Political Engagement in Africa. The Hague: Brill:317-336.

Mitchell C., De Lange N., Moletsane R. (2017b) Participatory Visual Methodologies: Social Change, Community and Policy. Thousand Islands: Sage.

Moletsane R., Mitchell C. (2018) Researching Sexual Violence with Girls in Rural South Africa: Some Methodological Challenges in Using Participatory Visual Methodologies. H.D. Shapiro (ed.) The Handbook on Violence in Education: Forms, Factors, and Preventions. Hoboken, NJ: Wiley Blackwell Publishing: 443-448.

Moletsane R., Mitchell C., Lewin T. (2015) Gender violence, teenage pregnancy and gender equity policy in South Africa: privileging the voices of women and girls through participatory visual methods. J. Parkes (ed.) Gender Violence in Poverty Contexts. New York: Taylor and Francis: 183-196.

Oinas E. (2011) The Girls who Won the Lottery. Conference on Contemporary, Girls, Embodiment and Social Change. Helsinki.

Rheingold H. (2008) Using Participatory Media and Public Voice to Encourage Civic Engagement. Civic Life Online: Learning how Digital Media Can Engage Youth:97-118. Available at: http://wiki.dbast.com/images/4/4b/Using_Participatory_Media_and_Public_Voice_ to_Encourage.pdf (accessed 22 August 2018).

Sinha M. (2013) Mesure de la violence faite aux femmes: tendances statistiques. Statistique Canada. Available at: http://www.statcan.gc.ca/pub/85-002-x/2013001/article/11766-fra.htm (accessed 8 July 2018).

Taft J.K. (2010) Rebel Girls: Youth Activism and Social Change across the Americas. New York: New York University Press.

Trigg M.K. (ed.) (2010) Leading the Way: Young Women's Activism for Social Change. New Brunswick, NJ: Rutgers University Press.

UNFPA (2016) How Our Future Depends on a Girl at This Decisive Age. Available at: https:// www.unfpa.org/sites/default/files/pub-pdf/The_State_of_World_Population_2016_-_English. pdf (accessed 7 June 2018).

United Nations (2018) Sustainable Development Goals. Available at: https://sustainabledevelopment.un.org/?menu=1300 (accessed 7 June 2018).

UN Women (2017) Facts and Figures: Ending Violence against Women. Available at: http:// www.unwomen.org/en/what-we-do/ending-violence-against-women/facts-and-figures (accessed 7 June 2018).

Wolfe D. A., Chiodo D. (2008) Sexual Harassment and Related Behaviors Reported among Youth from Grade 9 to Grade 11. Vancouver, BC: Centre for Addiction and Mental Health. 